\title{
QUALITY OF FUSARIOSIS-RESISTANT PINEAPPLE FRF 632, HARVESTED AT DIFFERENT MATURITY STAGES ${ }^{1}$
}

\author{
ELISETH DE SOUZA VIANA ${ }^{2 *}$, FABIANA FUMI CERQUEIRA SASAKI ${ }^{3}$, RONIELLI CARDOSO REIS ${ }^{2}$, DAVI \\ THEODORO JUNGHANS ${ }^{4}$, IOHANA SCARLET ALMEIDA GUEDES ${ }^{5}$, ELAINE GOES SOUZA ${ }^{3}$
}

\begin{abstract}
The objective of this study was to evaluate the influence of the harvest maturity stages on the physical, chemical and sensorial quality of the pineapple genotype FRF 632. The fruits were harvested in the maturity stages "green-ripe", "spotted", "colored" and "yellow" and evaluated regarding fruit and flesh mass; flesh yield; fruit and crown length; diameter of the basal, middle and top fruit sections; flesh color; titratable acididy (TA); translucency; soluble solids (SS); SS/TA ratio; and sensory acceptance of the attributes color, aroma, flavor, texture/firmness, overall acceptance and intensities of the attributes sweetness, acidity and firmness, using the just about right scale. There was no difference for the majority of the physical traits of the fruits at the various harvest maturity stages. The fruits had average mass of about 1,100 g. There was a gradual increase in the content of soluble solids and the SS/TA ratio during ripening. The fruits collected at the "colored" and "yellow" stages had the highest approval percentages and were considered to have ideal sweetness and acidity by the majority of consumers in sensorial tests. However, the preference mapping revealed a greater preference for fruits harvested in the "spotted" and "colored" stages for all the attributes assessed, unlike what was observed in the test of average and approval percentage. Therefore, the physical, chemical and sensorial tests indicate that the fruits harvested in the "colored" maturity stage were most preferred by consumers, since they had high approval percentage, as well as ideal sweetness and acidity.
\end{abstract}

Key words: Ananas comosus var. comosus. Sensory attributes. Harvest maturity stages.

\section{QUALIDADE DO ABACAXI FRF 632, RESISTENTE À FUSARIOSE, COLHIDO EM DIFERENTES ESTÁDIOS DE MATURAÇÃO}

RESUMO - O objetivo desse estudo foi avaliar a influência do ponto de colheita na qualidade física, química e sensorial do abacaxi FRF 632. Os frutos foram colhidos nos estádios de maturação "verdoso", "pintado" "colorido" e "amarelo" e avaliados quanto à massa do fruto e da polpa; rendimento em polpa; comprimentos do fruto e da coroa; diâmetros da base, da parte média, do ápice do fruto; cor da polpa; acidez titulável (AT); translucidez; sólidos solúveis (SS); relação SS/AT; aceitação sensorial dos atributos cor, aroma, sabor, textura/ firmeza e aceitação global e avaliação da intensidades dos atributos doçura, acidez e firmeza usando a escala do ideal. Não houve diferença para a maioria das características físicas dos frutos comparando-se os pontos de colheita. Os frutos apresentaram massa média em torno de $1.100 \mathrm{~g}$. Houve aumento gradativo no teor de sólidos solúveis e da relação SS/AT com o avanço dos estádios de maturação. Os frutos colhidos nos estádios "colorido" e "amarelo" apresentaram maiores percentuais de aprovação e foram considerados com doçura e acidez ideais pela maior parte dos consumidores. Entretanto, o mapa de preferência revelou uma maior preferência pelos frutos colhidos nos estádios "pintado" e "colorido", para todos os atributos avaliados, diferente ao que foi observado pelo teste de média e pelo percentual de aprovação. Portanto, ao considerar todos os testes físicos, químicos e sensoriais, conclui-se que os frutos colhidos no estádio "colorido" são os preferidos pelos consumidores, uma vez que apresentaram elevado percentual de aceitação, doçura e acidez ideais.

Palavras-chave: Ananas comosus var. comosus. Atributos sensoriais. Ponto de colheita.

\footnotetext{
${ }^{*}$ Corresponding author

${ }^{1}$ Received for publication in 09/04/2019; accepted in 02/20/2020.

Paper extracted from the results of the research project "Novas alternativas para a produção de abacaxi no semiárido baiano".

${ }^{2}$ Food Science and Technology Lab, Embrapa Cassava \& Fruits, Cruz das Almas, BA, Brazil; eliseth.viana@embrapa.br - ORCID: 00000003-4343-6536, ronielli.reis@embrapa.br - ORCID: 0000-0003-0475-3619.

${ }^{3}$ Post Harvest Lab, Embrapa Cassava \& Fruits, Cruz das Almas, BA, Brazil; fabiana.sasaki@embrapa.br - ORCID: 0000-0002-5342-6270, elaine.goes@embrapa.br - ORCID: 0000-0002-9886-8777.

${ }^{4}$ Embrapa Cassava \& Fruits, Cruz das Almas, BA, Brazil; davi.junghans@embrapa.br - ORCID: 0000-0003-1352-8317.

${ }^{5}$ Faculdade Maria Milza, Governador Mangabeira, BA, Brazil; iohanascarlet@gmail.com - ORCID: 0000-0003-3035-921X.
} 


\section{INTRODUCTION}

Pineapple is a tropical and subtropical nonclimacteric fruit that is well known for its juiciness, texture, high nutritional value, and pleasant flavor (LIU et al., 2017) and represents one of the leading fruits of the tropics worldwide (DIFONZO et al., 2019). Therefore, fusariosis, a disease caused by the fungus Fusarium guttiforme, is the main limitation on the pineapple production in the main producing regions in Brazil and other South American countries (SOUZA et al, 2016), since it causes losses in fruit production, depending on the initial concentration and growing season. The varieties most cultivated in the country, 'Pérola' and 'Smooth Cayenne', are susceptible to fusariosis limiting their production. The methods to control the disease can be chemical (fungicides), cultural (use of healthy seedlings and floral induction in periods unfavorable for the disease) and genetic (resistant cultivars) (PLOETZ, 2006).

The use of resistant cultivars is generally considered the best method to control fusariosis, because it is ecologically correct by not requiring the large-scale use of fungicides, thus reducing the negative impacts on the environment, producers and consumers who demand attractive fruit, free from diseases and toxic residues. Moreover, the minimum residue limits present in the edible portion of the fruit are often limited by strict regulations of importing countries (VILAPLANA; PÉREZREVELO; VALENCIA-CHAMORRO, 2018).

Since 1978, the Embrapa Cassava and Fruits research center has had a pineapple genetic breeding program, wich the main objective is developing fusariosis resistant cultivars with good quality fruits (CABRAL et al., 2009). The program has already led recommend of three resistant varieties: 'BRS Imperial' (CABRAL; MATOS, 2005), 'BRSAjubá' (CABRAL; MATOS, 2008) and 'BRS Vitória' (VENTURA et al., 2009). In turn, the genotype FRF 632 is an access of the Active Germplasm Bank (BAG) of Embrapa that is also resistant to fusariosis and has stood out in experiments conducted in the semiarid pineapple producing region in the state of Bahia for being tolerant to drought, with potential to be recommended as a new commercial cultivar.

The maturity stage in which fruits in general are harvested determines their quality. This is more important for pineapple, which is a non-climacteric fruit, meaning that it does not ripen after harvest. Harvesting pineapples before maturity therefore reduce their quality (CHITARRA; CHITARRA, 2005) and can cause rejection by consumers. However, the harvesting of fruits in an over-mature stage results in rapid loss of quality, reducing their shelf life. The best harvest stage depends on the interaction of the intrinsic physiological characteristics of each variety and the postharvest conservation technology employed (AZZOLINI; JACOMINO; SPOTO, 2004), so these are decisive to extend the shelf life (CHITARRA; CHITARRA, 2005) and assure satisfaction of the quality demands of consumers.

The maturity stages at which pineapples are harvested is usually determined by their use and the distance from the consumer market. Fruits appropriated for industrial processing, especially when the factory is near the field, can be harvested more ripe, when the level of total soluble solids and juice content are higher. However, fruits for in natura consumption should be harvested earlier, in general, before full maturity, so as to reach the point of sale while still in good condition for consumption (REINHARDT, 2000). However, to guarantee that fruits reach the market while still in minimum condition for sale, growers often harvest them before reaching the ideal stage, thus reducing the organoleptic quality.

Before a new variety is commercially launched, it is necessary to know the optimal maturity stage to harvest to assure the best quality characteristics, aiming a longer shelf life and high sensory acceptance by consumers. Therefore, the objective of this study was to evaluate the influence of harvest maturity stages on the physical and chemical characteristics and sensory acceptance of the pineapple genotype FRF 632.

\section{MATERIAL AND METHODS}

\section{Physical and chemical characterization}

Plants of the FRF 632 genotype were grown in the municipality of Cruz das Almas, Bahia state, and were harvested in October 2018. The plants were grown under drip irrigation in soil covered by a plastic mulch layer and received fertilization according to the soil analysis, following the recommendation for the 'Pérola' cultivar, since there is no fertilization recommendation for FRF 632 yet. To be evaluated, the fruits were harvested at four maturity stages (Figure 1), as defined Brazilian classification standard (CEAGESP, 2003): "greenripe" (mature fruit with completely green skin), "spotted" (center of the fruitlets yellow or up to $25 \%$ of the skin yellow-orange), "colored" (up to $50 \%$ of the fruitlets completely yellow) and "yellow" (more than $50 \%$ of the fruitlets yellow) to be evaluated.

The weights (in grams) of the whole fruit (with crown) and flesh were measured with a semi analytical balance. The flesh yield was calculated considering the flesh weight and weight of the whole fruit (with crown), expressed in percentage. The lengths (in centimeters) of the whole fruit and crown as well as the diameters at the basal, middle and top fruit section were measured with a pachymeter. The flesh color was rated on the scale indicated in the 
"Instructions for Performance of Distinguishability and Stability Tests of Pineapple Cultivars (Ananas comosus (L.) Merrill)", attributing the following scores: 1 - white to cream flesh; 2 - yellow flesh, 3 - golden-yellow flesh, and 4- orange flesh (BRASIL, 2003). The translucency was determined according to the scale described by Haff et al. (2006), where: 1 $=$ fruits with no translucency, $2=$ fruits with less than $25 \%$ of the flesh translucent, $3=$ fruits with 25 to $50 \%$ of the flesh translucent, $4=$ fruits with 50 to $75 \%$ of the flesh translucent, and $5=$ fruits with more than $75 \%$ of the flesh translucent. The levels of titratable acidity (TA, in \% of citric acid), soluble solids (SS, in ${ }^{\circ} \mathrm{Brix}$ ), $\mathrm{pH}$ and $\mathrm{SS} / \mathrm{TA}$ ratio were also measured, according to IAL (2008).

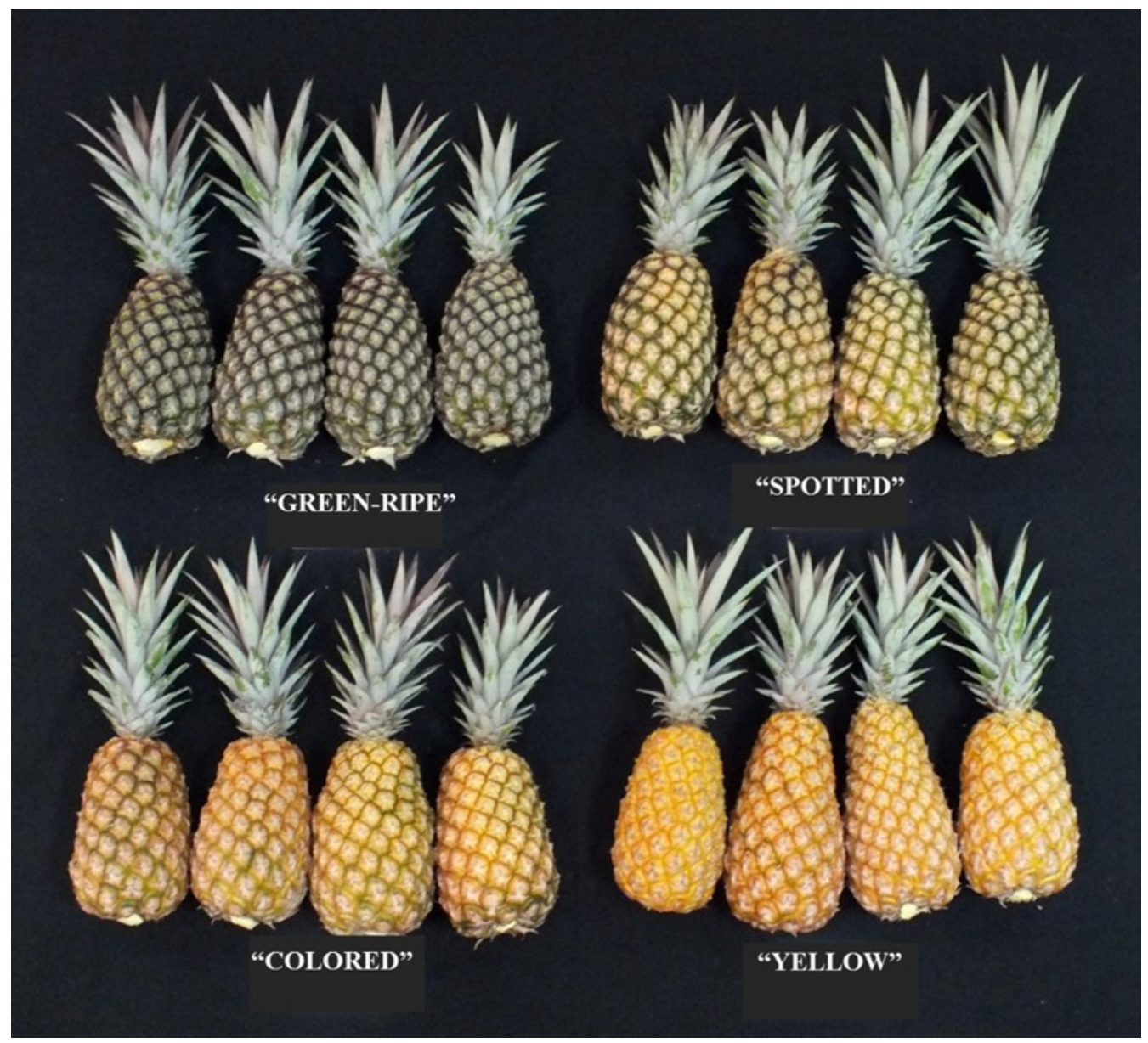

Figure 1. FRF 632 genotype ripening stages.

\section{Sensory evaluation}

The test of sensory acceptance was performed in individual booths by 59 untrained consumers. The fruits were washed, sanitized, peeled and cut into cubes and served to the consumers in $50 \mathrm{~mL}$ disposable cups, for evaluation of the attributes color, aroma, flavor, texture and overall acceptance, ranked on a nine-point hedonic scale, ranging from "I dislike strongly" to "I like strongly", according to the Brazilian standard NBR 14141 (ABNT, 1998). A five-point just about right (JAR) scale was applied for the intensities of the attributes sweetness, acidity and firmness, as described by Ferreira et al. (2000) and Berilli et al. (2011).

\section{Ethics Committee}

To participate in the sensory test, all the tasters signed the Informed Consent Form. The research project was approved by the Research Ethics Committee of Feira de Santana State University, under no. CAAE23109213.9.0000.5556.

\section{Statistical analyses}

The data from the physical, chemical and sensory testing were submitted to analysis of variance (ANOVA), and for the variables that had significant F-values, the Tukey test was used $(\mathrm{p}<0.05)$, using the Sisvar Program (FERREIRA, 2010). The percentage of scores greater than or equal to 6 was tallied to obtain the approval index. The results of the JAR scale test were presented as percentage. The acceptance data were also submitted to principal component analysis (PCA) based on the covariance matrix to obtain the internal preference 
mapping, using the Statistica 7.0 program (STATSOFT, 2008).

\section{RESULTS AND DISCUSSION}

\section{Physical, chemical evaluation}

The fruits harvested at the different maturity stages did not differ $(p>0.05)$ with respect to the physical characteristics as crown weight, fruit length, crown length, flesh yield and fruit diameter (basal, middle and top sections) (Table 1), indicating that after reaching the "green-ripe" stage there was no further increase in the fruit size of the genotype FRF 632. The fruits had average weight with crown of $1119 \mathrm{~g}$. The flesh weight was greater in the "yellow" than the "spotted" fruits (Table 1).

Table 1. Physical-chemical characteristics of pineapples of the 'FR632' genotype harvested at different maturity stages.

\begin{tabular}{lccccccc}
\hline Characteristic evaluated & Green-ripe & Spotted & Colored & Yellow & Mean & F & CV (\%) \\
\hline Fruit with crown weight $(\mathrm{g})$ & 1076.50 & 1152.00 & 1148.50 & 1099.00 & 1119.00 & $0.5316^{\text {n.s. }}$ & 7.58 \\
Flesh weight $(\mathrm{g})$ & $715.50 \mathrm{ab}$ & $784.50 \mathrm{a}$ & $765.00 \mathrm{ab}$ & $624.50 \mathrm{~b}$ & 722.38 & $0.0286^{*}$ & 9.57 \\
Flesh yield $(\%)$ & 72.50 & 74.29 & 73.03 & 62.34 & 70.54 & $0.01998^{\text {n.s. }}$ & 11.64 \\
Fruit length $(\mathrm{cm})$ & 17.03 & 17.80 & 16.93 & 18.28 & 17.51 & $0.3921^{\text {n.s. }}$ & 7.07 \\
Crown length $(\mathrm{cm})$ & 18.63 & 18.28 & 17.78 & 17.03 & 17.93 & $0.7649^{\text {n.s. }}$ & 12.46 \\
Fruit base diameter $(\mathrm{cm})$ & 9.75 & 9.88 & 9.85 & 9.60 & $9.77 \mathrm{~A}$ & $0.6833^{\text {n.s. }}$ & 3.58 \\
Fruit midsection diameter $(\mathrm{cm})$ & 9.58 & 9.95 & 9.93 & 9.68 & $9.78 \mathrm{~A}$ & $0.4879^{\text {n.s. }}$ & 4.04 \\
Fruit apex diameter $(\mathrm{cm})$ & 7.08 & 8.00 & 7.85 & 7.30 & $7.56 \mathrm{~B}$ & $0.0558^{\text {n.s }}$ & 6.37 \\
Flesh color & $1.00 \mathrm{~b}$ & $1.00 \mathrm{~b}$ & $2.00 \mathrm{a}$ & $2.00 \mathrm{a}$ & 1.50 & $0.0000^{*}$ & 0.00 \\
Translucency & 1.00 & 1.00 & 1.00 & 1.00 & 1.00 & $0.0000^{\text {n.s. }}$ & 0.00 \\
Titratable acididy & 0.77 & 0.83 & 0.89 & 0.85 & 0.83 & $0.0928^{\text {n.s. }}$ & 7.23 \\
$(\%$ citric acid) & $8.84 \mathrm{~b}$ & $9.83 \mathrm{~b}$ & $10.99 \mathrm{~b}$ & $14.26 \mathrm{a}$ & 10.98 & $0.0002^{*}$ & 10.88 \\
Soluble solids $\left({ }^{\circ}\right.$ Brix) & $10.58 \mathrm{c}$ & $11.17 \mathrm{bc}$ & $14.69 \mathrm{ab}$ & $17.14 \mathrm{a}$ & 13.40 & $0.0007^{*}$ & 13.51 \\
SS/TA ratio & & & & & & &
\end{tabular}

*significant at $5 \%$ probability by the by test; n.s. not significant. Means followed by equal letters, lowercase in the row and uppercase in the column, do not differ by the Tukey test at $5 \%$.

In general, this genotype produced lighter fruits than those of the traditional cultivars Pérola and Smooth Cayenne, which have mean weights of 1.2 to $1.5 \mathrm{~kg}$ and 1.5 to $2.1 \mathrm{~kg}$, respectively (ALMEIDA et al., 2004). However, larger fruits might be obtainable by adjusting the growing conditions.

With regard to shape, there was also no difference between the maturity stages. All the fruits had top section diameters smaller than those at the basal and middle section diameter (Table 1), showing that this genotype produces fruits with conical to cylindrical shape according to the classification defined by the Brazilian Ministry of Agriculture for pineapple cultivars (BRASIL, 2003).

With respect to flesh color, the fruits harvested at the "green-ripe" and "spotted" stages had score corresponding to "white to cream" color, differing statistically $(\mathrm{p} \leq 0.05)$ from the fruits collected at the "colored" and "yellow" stages, which had yellow color (Table 1). The flesh color of the fruits changed from "white to cream" to "yellow" during ripening. According to Lobo and Yahia (2017), this change in flesh color of pineapples is due to the accumulation of carotenoids.

There was no difference in translucency between the maturity stages, all of the fruits had average score of 1.0 (absence of translucency). The translucency, also called porosity, is associated with greater sensitivity of fruits to mechanical injury, due to the intercellular free spaces being filled with liquid (PAULL; CHEN, 2014). This result suggests that the fruits of the FRF 632 genotype can be more resistant to mechanical damage, facilitating the handling and transport, because even at the most advanced ripeness stage they were not translucent.

The maturity stage did not have a significant influence on titratable acididy level, with average of $0.83 \%$ citric acid (Table 1 ). The acidity level observed is well above that observed by Reinhardt et al. (2004), who reported a significant decline of titratable acididy in 'Pérola' pineapple cultivated in Itaberaba, Bahia, when advancing from the "greenripe" $(0.55 \%)$ to the "colored" stage $(0.37 \%)$. In turn, Viana et al. (2013) reported similar average acidity $(0.88 \%)$ for fruits of various genotypes, including the cultivars 'Pérola' and 'Smooth Cayenne', also grown in Cruz das Almas, Bahia.

During the ripening, there was an increase of soluble solids content and the SS/TA ratio of the fruits, reaching the highest values for those harvested at the "yellow" stage (Table 1). Reinhardt et al. (2004) observed higher levels of soluble solids and SS/TA ratio in 'Pérola' pineapples harvested at the 
"colored" stage (SS $=14.57{ }^{\circ}$ Brix and SS/TA = 41.46) in relation to those harvested at the "greenripe" stage $\left(\mathrm{SS}=12.95^{\circ}\right.$ Brix and $\left.\mathrm{SS} / \mathrm{TA}=24.18\right)$. In pineapple, the predominant sugars are sucrose, fructose and glucose, which together compose 7 to $12 \%$ of fresh weight, with the peak sucrose value reached in the "yellow" stage, and declining thereafter (LOBO; YAHIA, 2017).

\section{Sensory assessment}

The consumers liked the FRF 632 fruits, because they attributed scores higher than 6 to all the samples, with approval percentage above $70 \%$ for all sensory attributes (Table 2). However, the scores given to the sensory attributes of the "yellow" fruits were better than those assigned to the "green-ripe" fruits, which were classified in hedonic terms as "I like slightly" or "I like moderately" for all the attributes evaluated, indicating lesser acceptance of the fruits harvested at this maturity stage. Miguel et al. (2010) obtained different results in the sensory evaluation of the 'Pérola' cultivar, since the fruits harvested at the "spotted" and "colored" stages were preferred by the test consumers. According to the authors, the consumers mentioned as desirable aspects of pineapple high sweetness, low to moderate acidity, tender consistency, attractive succulence and color (more yellowish flesh).

Regarding the approval percentage (scores equal to or greater than 6.0), the highest values were found for the fruits harvested at the "colored" and "yellow" stages, indicating these were the stages preferred for fresh consumption (Table 2). This acceptance pattern of the "colored" and "yellow" stages corresponds to the SS/TA ratio obtained for the fruits in these stages (Table 1), because this ratio directly reflected the flavor perception of the consumers. Jintana, Adisak and Chatlada (2011) reported that the SS/TA ratio has a direct positive effect on the acceptance of fresh pineapples. The absence of a significant difference in the level of titratable acidity indicated that the acceptance of consumers of the FRF 632 genotype was more closely related to the content of soluble solids than the acidity (Table 1).

Table 2. Mean hedonic values and approval percentages of FRF 632 pineapple harvested at different maturity stages.

\begin{tabular}{lccccccc}
\hline Attribute & & Green-ripe & Spotted & Colored & Yellow & F & CV (\%) \\
\hline \multirow{2}{*}{ Flesh color } & Mean $^{1}$ & $6.69 \mathrm{~b}$ & $7.20 \mathrm{ab}$ & $7.08 \mathrm{ab}$ & $7.41 \mathrm{a}$ & $0.0039^{*}$ & 15.08 \\
& Approv $^{2}$ & 86 & 90 & 98 & 97 & - & - \\
\hline \multirow{2}{*}{ Aroma } & Mean $^{1}$ & $6.46 \mathrm{~b}$ & $6.61 \mathrm{ab}$ & $7.08 \mathrm{a}$ & $7.15 \mathrm{a}$ & $0.0020^{*}$ & 17.32 \\
& Approv $^{2}$ & 73 & 80 & 92 & 88 & - & - \\
\hline \multirow{2}{*}{ Flavor } & Mean $^{1}$ & $6.47 \mathrm{~b}$ & $6.90 \mathrm{ab}$ & $7.10 \mathrm{ab}$ & $7.25 \mathrm{a}$ & $0.0146^{*}$ & 19.11 \\
& Approv $^{2}$ & 83 & 86 & 88 & 90 & - & - \\
\hline \multirow{2}{*}{ Texture/firmness } & Mean $^{1}$ & $6.32 \mathrm{~b}$ & $6.85 \mathrm{ab}$ & $7.02 \mathrm{a}$ & $7.24 \mathrm{a}$ & $0.0002^{*}$ & 17.45 \\
& Approv $^{2}$ & 80 & 86 & 93 & 90 & - & - \\
\hline \multirow{2}{*}{ Overall impression } & Mean $^{1}$ & $6.24 \mathrm{~b}$ & $6.90 \mathrm{a}$ & $7.14 \mathrm{a}$ & $7.27 \mathrm{a}$ & $0.0000^{*}$ & 17.64 \\
& Approv $^{2}$ & 75 & 88 & 95 & 95 & - & - \\
\hline
\end{tabular}

(1) Mean hedonic scores $(\mathrm{n}=59)$ on a nine-point scale, ranging from "I dislike strongly" (1) and "I like strongly" (9); (2) Approv: approval, with the results expressed as percentage of scores $\geq 6$. Means followed by equal letters in the row do not differ by the Tukey test at $5 \%$.

*significant at $5 \%$ probability by the $\mathrm{F}$ test.

The results show that from a sensory standpoint, the FRF 632 fruits harvested in the "colored" and "yellow" stages were superior than observed by Berilli et al. (2011) with 'Pérola' pineapples harvested in the "yellow" stage for the attributes aroma (5.9), flavor (6.5) and overall impression (6.7) and were similar to the averages found by those authors for the 'Gold' cultivar, which presented acceptance levels of 7.2 for aroma, 7.7 for flavor and 7.4 for overall impression.

On the just about scale, the highest number of consumers indicated that the sweetness and acidity of the fruits were ideal at the maturity stages "colored" and "yellow" (Figure 2), corroborating the results of the hedonic test (Table 2), as well as the higher SS/TA ratio of the fruits in these stages (Table 1). More than $60 \%$ of the consumers considered the texture to be ideal of the fruits in all four maturity stages, but the texture of the fruits in the "yellow" stage was considered ideal by over $70 \%$ of the consumers (Figure 1). Texture is a critical quality attribute to determine the acceptance of fruits and vegetables. Changes that occur in the cell walls during fruit ripening, storage and cooking are fundamental for the texture of the final product (ABBOTT; HARKER, 2016). During the ripening of fruits, cell wall alterations occur, including solubilization and degradation of pectin and degradation of non-cellulosic neutral sugars such as galactose and arabinose, as well as narrowing of the molecular weight distribution of hemicelluloses (HARKER et al. 1997), resulting in changes in texture. In this study, we observed that the consumers preferred the texture of pineapple FRF 632 in the more advanced maturity stages. 

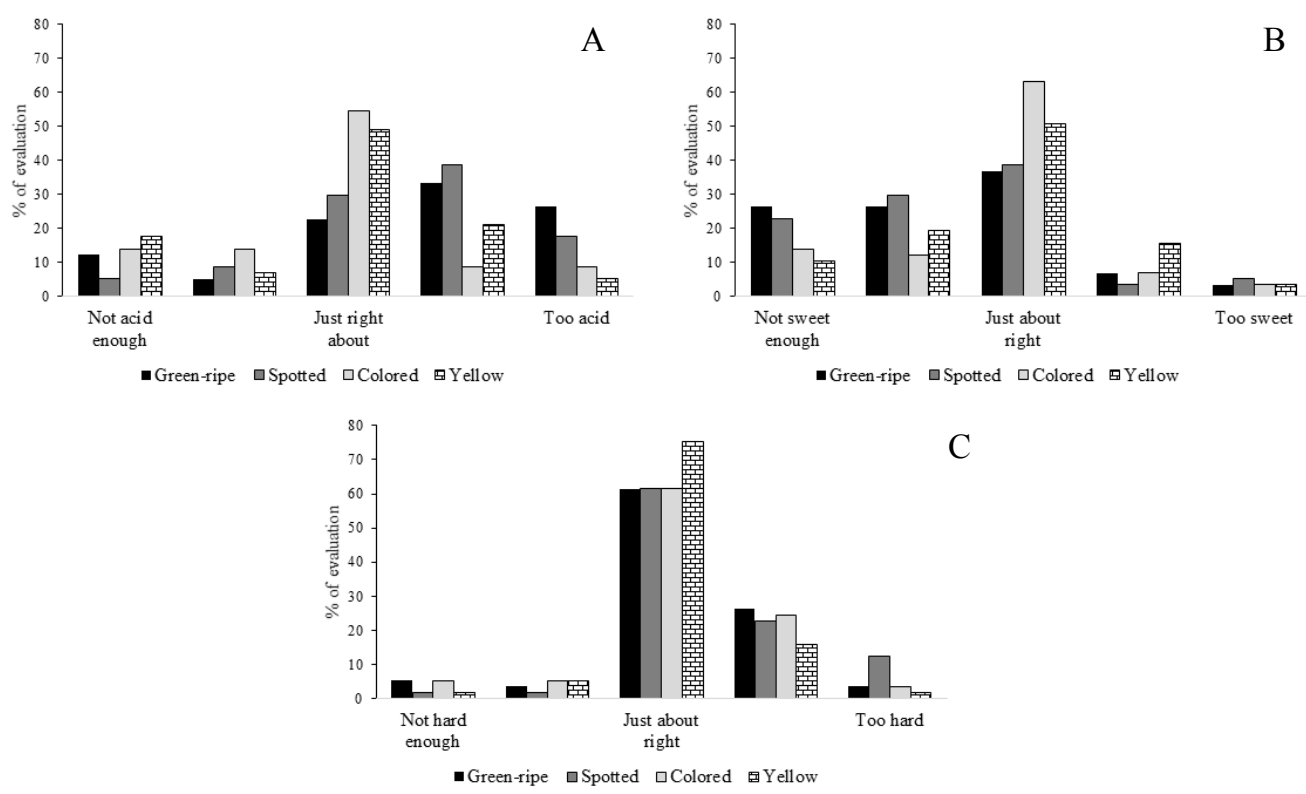

Figure 2. Evaluation of the acidity (A), sweetness (B) and texture/firmness (C) of pineapple FRF 632 harvested at different maturity stages.

The internal preference mapping generated from the acceptance data for the attributes appearance, color, aroma, flavor and texture are presented in Figure 3. The dispersion of the samples represents the differences in acceptance between the maturity stages by the consumers for each attribute evaluated (Figures 3.1, 3.3, 3.5, 3.7 and 3.9), while each point denotes a consumer (Figures 3.2, 3.4, 3.6, 3.8 and 3.10). The consumers positioned in the central region of the graph did not present significant correlations $(\mathrm{p} \geq 0.05)$ with the two principal components, so those consumers did not distinguish the samples in relation to the attributes evaluated.

For all the attributes, the first two principal components were greater than $73 \%$, explaining most of the variance of the data. Therefore, the graph is two-dimensional with easy interpretation.

In general, the internal preference mapping presented an advantage in relation to the analysis of variance and mean test, because it allowed identifying clear differences in the acceptance between the fruits harvested at the four maturity stages and the individual preferences of each consumer, making it an efficient assessment tool.

With respect to color (Figure 3.1), the first two principal components explained $76.05 \%$ of the variance of the acceptance data. The majority of consumers are located on the left side of the graph (Figure 3.2), indicating higher preference for the pineapples harvested at the maturity stages "spotted" (B) and "colored" (C). A small group of consumers preferred the fruits harvested at the "green-ripe" (A) and "yellow" stages (D). Comparison of this result with those of the means test for color (Table 2) reveals divergence of the results obtained by the two evaluation methods. The preference mapping clearly shows preference for fruits of the "spotted" and "colored" stages, while in the mean test, there was no difference of the "spotted", "colored" and "yellow" stages. This can be explained by the fact that the mean test considers the average score attributed by the 59 tasters, while the preference mapping depicts the individual evaluation of each consumer.

In the preference mapping for the aroma attribute, the two principal components explained $74.05 \%$ of the variance of the data, of which PC1 explained the greatest share (43.68\%) (Figure 3.3). Samples B ("spotted") and C ("colored"), located on the right of the graph, were considered similar by the consumers in relation to this attribute and were preferred by the majority of the consumers (Figure 3.4). According to the means test (Table 2), the fruits in categories B ("spotted"), C ("colored") and D ("yellow") did not differ regarding acceptance, while the preference mapping allowed identifying differences in acceptance of these three stages.

For the flavor attribute (Figure 3.5), the first principal component (PC1) explained $42.02 \%$ and the second component (PC2) $31.77 \%$ of the variance of acceptance among the four stages. The first two principal components thus explained $73.79 \%$ of the total variance of the acceptance data. For this attribute, it can be seen that the acceptance vectors grow in the directions of the second, third and fourth quadrants, indicating a more homogeneous distribution of the consumers' preference among the samples. Stage C ("colored") was preferred by the consumers located in the left part of the graph, while B ("spotted") was preferred by the consumers situated in the lower part, with these two stages having the highest preference. A smaller number of consumers, located in the upper part of the graph, expressed preference for stages A and D (Figure 3.6). 


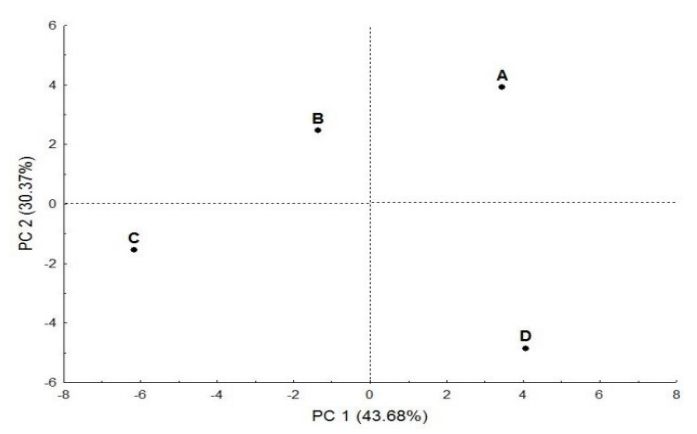

1

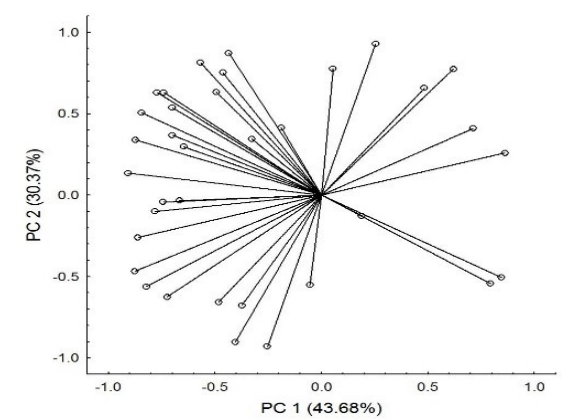

2

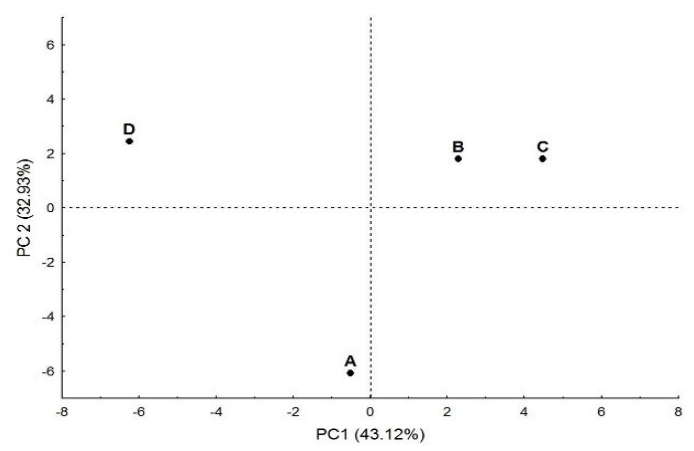

3

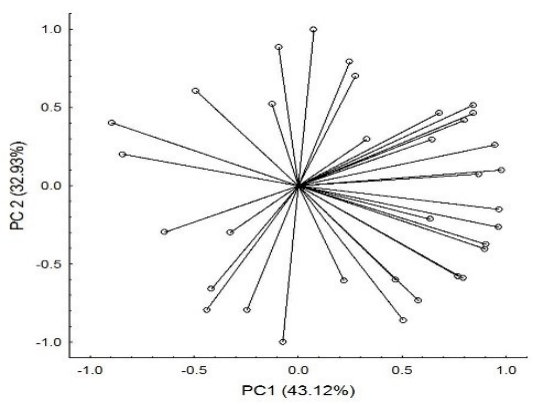

4

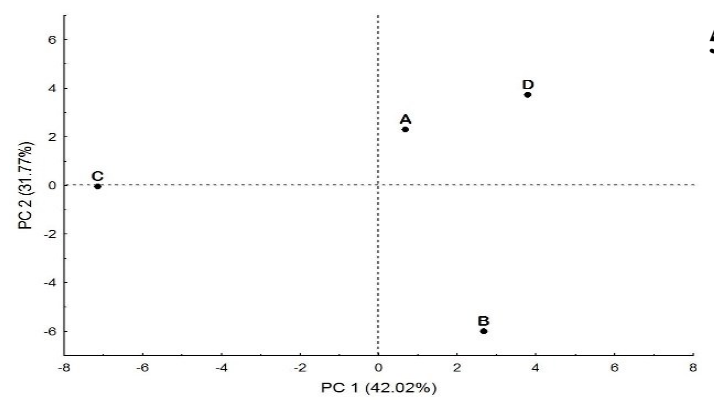

5

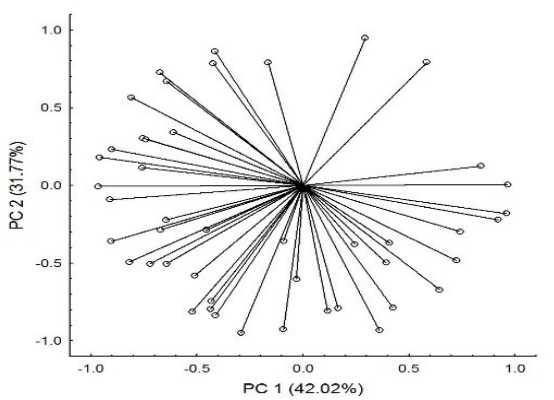

6
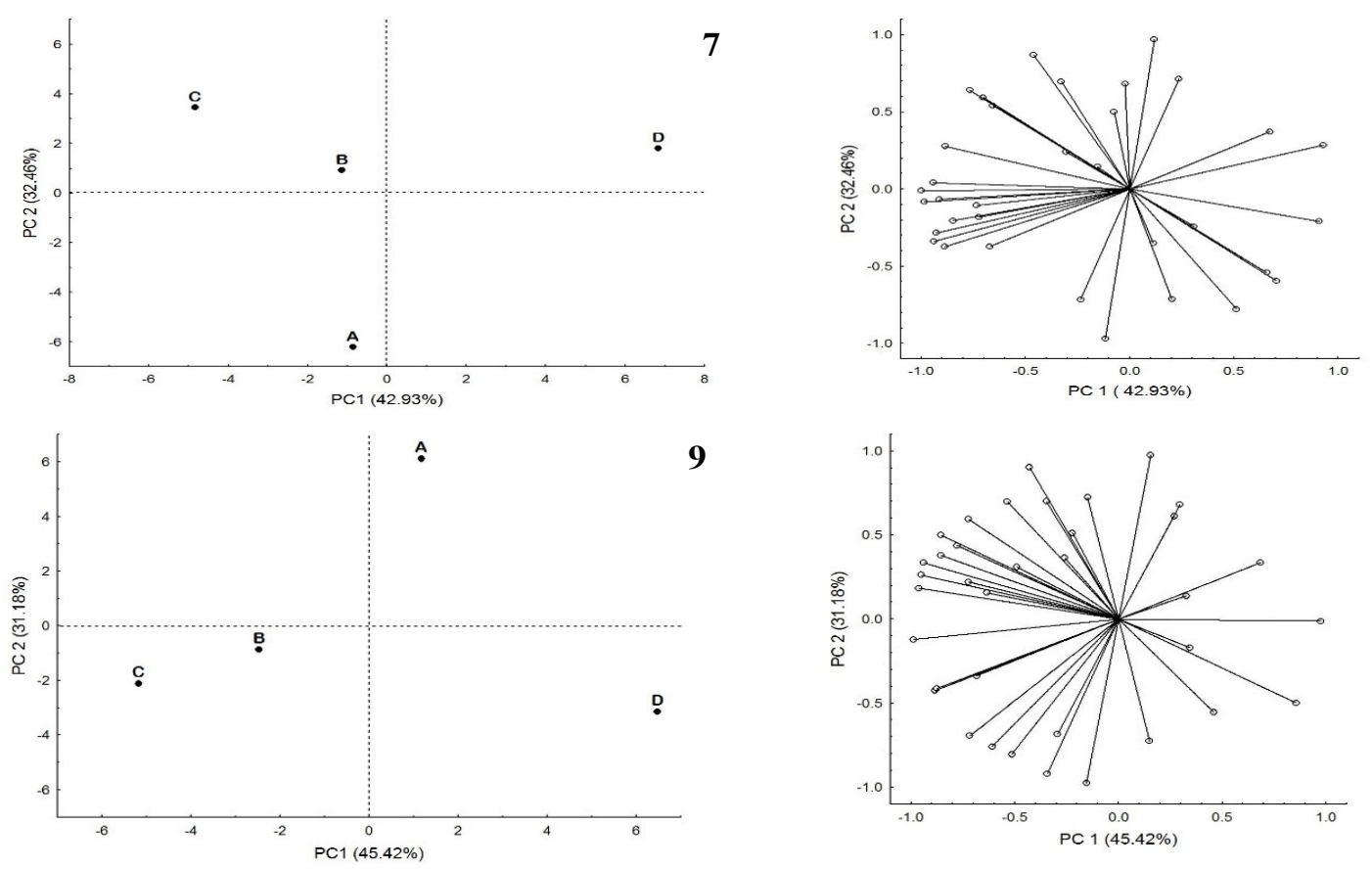

8

10

Figure 3. Internal preference mapping of pineapple 'FRF 632' fruits harvested at different maturity stages. A - "greenripe"; B - "spotted"; C - "colored"; D - "yellow". Dispersion of the samples in relation to acceptance of color (1), aroma (3), flavor (5), texture (7) and overall impression (9) (10). Correlation between the acceptance data color (2), aroma (4), flavor (6), texture (8) and overall impression of each consumer and the first two principal components (PC1 and PC2). 
Figures 3.7 and 3.8 show the internal preference mapping for texture attribute. The two principal components explained $75.39 \%$ of the variance of the acceptance data. The preference vectors grow in the direction of the stages $\mathrm{B}$ ("spotted") and C ("colored"), while a smaller number of consumers expressed preference for stages A ("green-ripe") and D ("yellow"), unlike indicated by the results in Table 2 .

In relation to the overall impression attribute, PC1 explained $45.42 \%$ of the variance of the acceptance data and PC2 $31.18 \%$, for a total of $76.6 \%$ (Figure 3.9 ). The majority of consumers are positioned in the left part of the graph, indicating preference for the fruits harvested in stages B ("spotted") and C ("colored") (Figure 3.10).

Overall analysis of the preference mapping of the acceptance data show that fruits of stages "spotted" and "colored" were preferred by the consumers in relation to all the attributes assessed. However, when considering the approval percentages and ideal scale, the results indicate preference for the "colored" and "yellow" stages.

\section{CONCLUSIONS}

The harvest stage did not influence the physical and chemical quality of the pinapple FRF 632 , but the SS/TA ratio, which indicates the flavor of the fruits, was better in the "colored" and "yellow" stages.

Therefore, it can be concluded that the ideal maturity stage to harvest pineapple fruits of the genotype FRF 632 is the "colored" stage, since these fruits presented high approval percentages, were considered to have ideal acidity and sweetness, and according to the preference mapping, were preferred by the majority of the consumers.

\section{ACKNOWLEDGEMENTS}

The authors are incredibly grateful to Fundação de Amparo à Pesquisa do Estado da Bahia (FAPESB) for financial support.

\section{REFERENCES}

ABBOTT, J. A.; HARKER, F. R. Texture. In: GROSS, K.C., WANG, C.Y., SALTVEIT, M. (Eds). The commercial storage of fruits, vegetables, and florist and nursery stocks. Washington: USDA, 2016, p. 89-110. (USDA Agriculture Handbook, 66).

ASSOCIAÇÃO BRASILEIRA DE NORMAS TÉCNICAS - ABNT. Escalas utilizadas em análise sensorial de alimentos e bebidas - NBR 14141. Rio de Janeiro: ABNT, 1998.

ALMEIDA, C. O. et al. Peso médio do abacaxi no Brasil: um tema em discussão. Bahia Agrícola, 6: 41 $-46,2004$.

AZZOLINI, M.; JACOMINO, A. P.; SPOTO, M. H. F. Maturation stage and postharvest quality of 'Pedro sato' guavas. Revista Brasileira de Fruticultura, 26: 29-31, 2004.

BERILLI, S. S. et al. Sensory evaluation of fruits of pineapple cultivars for in natura consumption. Revista Brasileira de Fruticultura, 33: 592-598, 2011.

BRASIL. Ministério de Agricultura, Pecuária e Abastecimento / Secretaria de Apoio Rural e Cooperativismo / Serviço Nacional de Proteção de Cultivares. Instruções para Execução dos Ensaios de Distinguibilidade, Homogeneidade e Estabilidade de Cultivares de Abacaxizeiro (Ananas comosus (L.) Merrill). 2003

CABRAL, J. R. S. et al. Pineapple Genetic Improvement in Brazil. Acta Horticulturae, 822: 39 $-46,2009$.

CABRAL, J. R. S.; MATOS, A. P. Imperial, nova cultivar de abacaxi. Cruz das Almas, BA: Embrapa Mandioca e Fruticultura, 2005. 4 p. (Embrapa Mandioca e Fruticultura. Comunicado Técnico, 114)

CABRAL, J. R. S.; MATOS, A. P. BRS Ajubá, nova cultivar de abacaxi. Cruz das Almas, BA: Embrapa Mandioca e Fruticultura Tropical, 2008. 4 p. (Embrapa Mandioca e Fruticultura Tropical. Comunicado técnico, 126).

\begin{tabular}{llll} 
COMPANHIA & \multicolumn{1}{c}{ DE } & \multicolumn{2}{c}{ ENTREPOSTOS } \\
ARMAZÉNS & GERAIS & DE & SÃO PAULO \\
CEAGESP. & Programa & brasileiro para
\end{tabular} modernização da horticultura: normas de classificação do abacaxi. São Paulo, Central de Qualidade em Horticultura, 2003 (CQH. Documentos, 24). Disponível em: <http:// www.ceagesp.gov.br/entrepostos/servicos/produtos/ classificacao/>. Acesso em: 15 fev 2019.

CHITARRA, M. I. F.; CHITARRA, A. B. Póscolheita de frutos e hortaliças: fisiologia $e$ manuseio. 2. ed. Lavras, MG : UFLA, 2005. 785 p.

DIFONZO, G. et al. Characterisation and classification of pineapple (Ananas comosus [L.] Merr.) juice from pulp and peel. Food Control, 976: 260-270, 2019. 
FERREIRA, D. F. SISVAR - Sistema de análise de variância. Versão 5.3. Lavras-MG: UFLA, 2010.

FERREIRA, V. L. P. et al. Análise sensorial: testes discriminativos e afetivos. Campinas, SP: SBCTA, 2000. 127 p. (Manual - Série Qualidade).

HAFF, R. P. et al. X-Ray assessment of translucency in pineapple. Journal of Food Processing and Preservation, 30: 527-533, 2006.

HARKER, F. R. et al. Texture of fresh fruit. Horticultural Reviews, 20: 121-224, 1997.

INSTITUTO ADOLFO LUTZ - IAL. Métodos físico-químicos para análise de alimentos. 4. ed. Brasília, DF: Ministério da Saúde, 2008. 1018 p.

JINTANA J.; ADISAK J.; CHATLADA W. Relationship between chemical properties and acceptability of 'Smooth Cayenne' Pineapple. Acta Horticulturae, 902: 453-458, 2011.

LIU, J. et al. The crown plays an important role in maintaining quality of harvested pineapple. Postharvest Biology and Technology, 124: 18-24, 2017.

LOBO, M. G.; YAHIA, E. Biology and postharvest physiology of pineapple. In: LOB, M.G; PAULL, R.E. (Eds.) Handbook of pineapple technology: production, postharvest science. London: John Wiley \& Sons Ltda, 2017, cap. 3, p. 39-61.

MIGUEL, A. C. A. et al. Modificações sensoriais em abacaxi 'Pérola' armazenado à temperatura ambiente. Ciência e Tecnologia de Alimentos, 30: 20-23, 2010.

PAULL, R. E.; CHEN, C. C. Pineapple: postharvest quality-maintenance guidelines. Fruit, Nut, and Beverage Crops, 2: 1-6, 2014.

PLOETZ, R. C. Fusarium-induced diseases of tropical, perennial crops. Phytopathology, 96: 648652, 2006.

REINHARDT, D. H. R. C. Colheita e beneficiamento. In: GONÇALVES, N. B. (Ed.) Abacaxi: pós-colheita. Brasília: Embrapa Comunicação para Transferência de Tecnologia, 3, 2000, cap. 3, p. 28-37. (Frutas do Brasil, 5).

REINHARDT, D. H. R. C. et al. Gradientes de qualidade em abacaxi 'pérola' em função do tamanho e do estádio de maturação do fruto. Revista Brasileira de Fruticultura, 26: 544-546, 2004.
STATSOFT. Statistics for Windows 7.0. Tulsa, OK: StatSoft, Inc. 2008.

SOUZA, et al. Plants from the Caatinga biome harbor endophytic Trichoderma species active in the biocontrol of pineapple fusariosis. Biological Control, 94: 25-32, 2016.

VENTURA, J. A. et al. 'Vitória': New Pineapple Cultivar Resistant to Fusariosis. Acta Horticulturae, 822: 51-56, 2009.

VIANA, E. S. et al. Physico-chemical characterization of new hybrids pineapple resistant to fusariosis. Ciência Rural, 43: 155-1161, 2013.

VILAPLANA, R; PÉREZ-REVELO, K.; VALENCIA-CHAMORRO, S. Essential oils as an alternative postharvest treatment to control fusariosis, caused by Fusarium verticillioides, in fresh pineapples (Ananas comosus). Scientia Horticulturae, 238: 255-263, 2018. 